\title{
Evaluation of Groundwater Resources of the Middle Niger (Bida) Basin of Nigeria
}

\author{
Olus ola T. Olabode ${ }^{1}$, Martin O. Eduvie ${ }^{1}$, Is aac O. Olaniyan ${ }^{2, *}$ \\ ${ }^{1}$ National Water Resources Institute, Kaduna, Nigeria \\ ${ }^{2}$ Department of Phy sical Sciences, Ondo State University of Science and Technology, Okitipupa, Nigeria
}

\begin{abstract}
The Middle Niger Basin lies in the sedimentary terrains of the middle part of Nigeria. It has an area coverage of about $27,000 \mathrm{~km}^{2}$. The area falls under the middle Nigeria climatic belt which is mainly tropical with an average rain fall of about $1250 \mathrm{~mm}$. This paper evaluates the hydrogeological potential of the terrain. The methods of investigation include analysis of meteorological, drilling, pumping tests and water quality data. A total of about 50 boreholes located in the area were selected for study. Results of the analyses of the data showed that groundwater occurs both in confined and semi-confined conditions. Depth to water rarely exceeds $50 \mathrm{~m}$, though in some few cases may be over $70 \mathrm{~m}$. Averagely, well yield varies between 1.08 and $19 \mathrm{~m}^{3} / \mathrm{hr}$. Transmissivity values obtained using various methods vary between 1.365 and $393 \mathrm{~m}^{2} /$ day. Hydrochemical analyses of groundwater samples showed poor mineralization with low TDS (Total Dissolved Solids) rarely over $300 \mathrm{mg} / 1$. The water is fresh, soft and free of chemical pollution and therefore suitable for many purposes.
\end{abstract}

Keywords Evaluation, Niger Basin, Groundwater, Hydrochemical Analyses, Transmissivity

\section{Introduction}

\subsection{The Study Area and Collection of Data}

The Middle Niger Basin stretches between longitudes $4^{\circ} \mathrm{E}$ to $7^{\circ} \mathrm{E}$ and latitudes $7^{\circ} \mathrm{N}$ to $12^{\circ} \mathrm{N}$ occupying parts of Niger, Kwara, Kogi States and Federal Capital Territory (Figure 1). The climate is moist sub-humid according to Thornthwaite's classification. The mean average annual temperature varies from $26.5^{\circ} \mathrm{C}$ to $27.8^{\circ} \mathrm{C}$. The area experiences two distinct seasons: the wet seas on which extends from April to October and a dry season between November to March. The rainy season is characterized by heavy downpours accompanied by groundwater infiltration and percolation. Average annual rainfall ranges between 1000 to $1500 \mathrm{~mm}$.

The area is of low to moderate relief with a few scattered laterite-capped hills where elevations rarely exceed $400 \mathrm{~m}$ above sea level. The area is generally well drained. A regional dendritic pattern is most prominent; however, rectilinear patterns are occasionally exhibited by the short tributaries. River Niger is the most significant drainage element in the area, having its main tributaries as Kaduna, Gbako, Gurara, Chanchaga and Kampe rivers.[1, 2]. The area is sparsely populated with agriculture being the main activity in the area. There are several large-scale agricultural

* Corresponding author:

dejoolaniyan@gmail.com (Isaac O. Olaniyan)

Published online at http://journal.sapub.org/ajee

Copyright (C) 2012 Scientific \& Academic Publishing. All Rights Reserved projects in the area.

A total of about 50 boreholes drilled in the study area were used in the compilation of this report. Most of these boreholes were drilled by the Geological survey of Nigeria, Federal Department of Water Resources, Preussag Drilling Engineers, National Water Resources Institute (NWRI) and other private drilling engineers. The data compiled from these boreholes are presented in Table 1. Aquifer characteristics such as transmissivity, hydraulic conductivity, specific yield were determined through pumping test data analys is for boreholes especially where required data for the calculation of these parameters are available. Water quality analys is of some of the boreholes selected for study were carried out by the Hydrogeology Department of NWRI Kaduna. These were supplemented by existing water quality data in the study area.

All the above data were used to draw up a conclusion on the groundwater situation in the basin.

\subsection{Stratigraphy and Sedimentation}

The stratigraphy of geological units which occur in the investigated area is given after Dessauvagie[3]. The Bida sandstone is the basal sediment of the Middle Niger Basin and it consist mainly of fine to coarse grained sandstones, conglomerates, siltstones and claystones. The sandstone which underlies the Mokwa and Kontagora plains are generally angular to sub-angular, well sorted to poorly sorted and very fine to very coarse and pebbly. The occurrence of Sakpe ironstone formation is limited to the slopes of mesas belt between Bida town and River Niger. The formation 
overlies conformably the beds of Bida sandstone. It consists of coarse-grained oolitic ironstones, dark brown to dark yellow in colour.

The Enagi siltstone formation lies directly on the Bida sandstone. The siltstones are commonly laminated to thinly laminated. The thickness varies from 10 to $70 \mathrm{~m}$. The Batati formation occupies the highest stratigraphical position among the sedimentary series of the Nupe sandstone. Around Bida they are referred to as the Batati Ironstone formation and the Agbaja Ironstone formation around the
Niger/Benue Confluence[4]. The alluvial deposits reach considerable thickness and extension particularly in the main river valleys of Niger, Benue and Kaduna. These sediments consist of unconsolidated gravels coarse to fine sands, silts and clays which have been deposited in and along river channels. Figure 2 shows the geological map of the study area.

\section{Hydrogeological Situation}

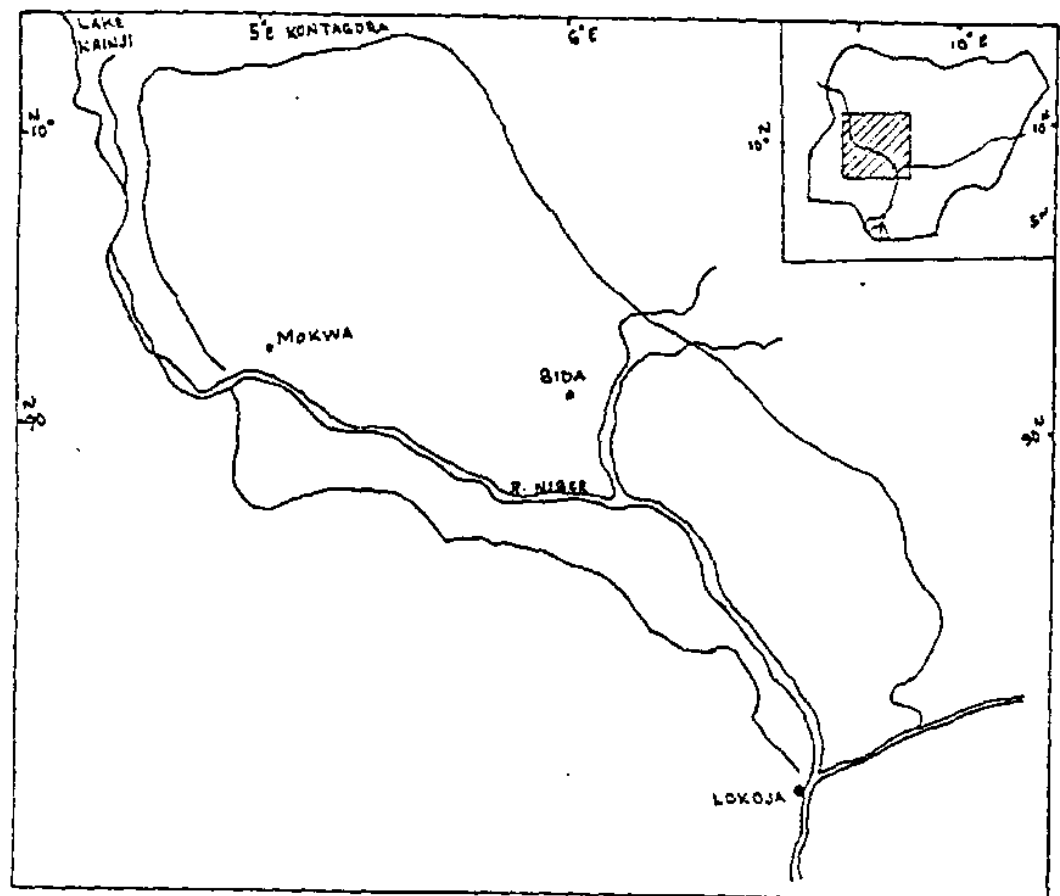

Figure 1. Location of the Study Area

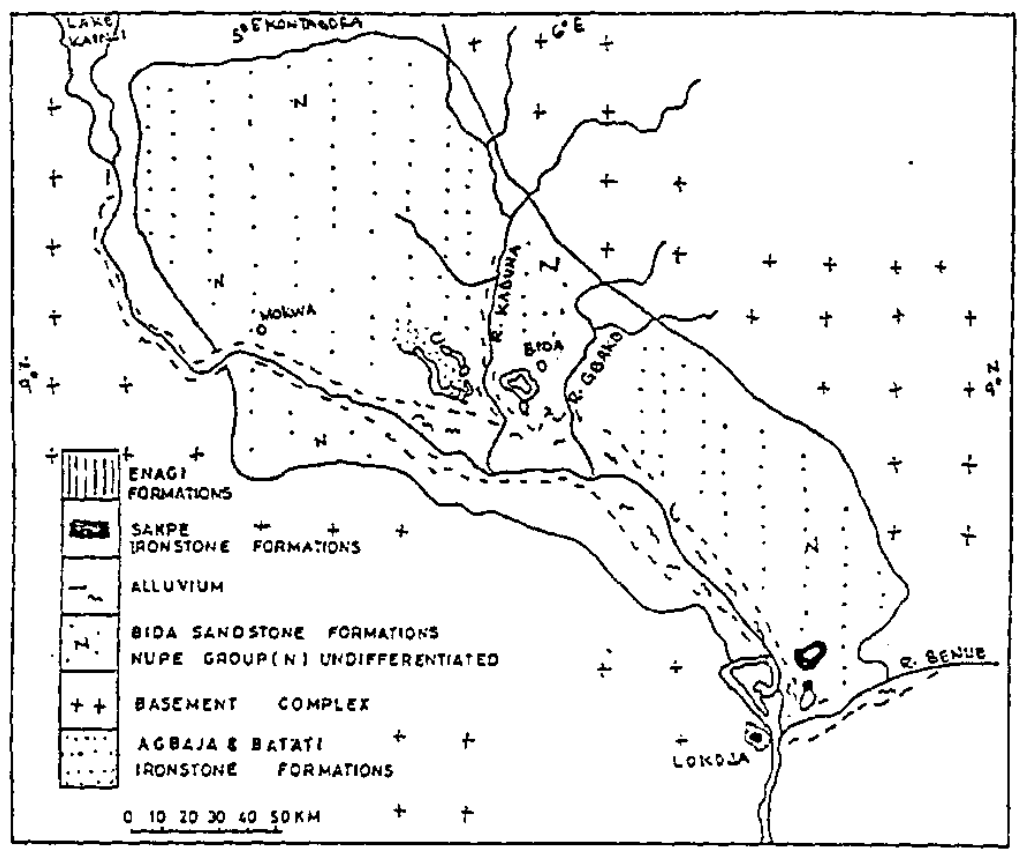

Figure 2. Geological Map of the Study Area 
Table 1. Borehole Inventories in the Study Area

\begin{tabular}{|c|c|c|c|c|c|c|c|c|c|c|c|c|}
\hline Locality & $\begin{array}{c}\text { Altitude } \\
\text { (m) } \\
\text { (A.S.L) }\end{array}$ & $\begin{array}{c}\text { Total } \\
\text { Depth } \\
(\mathrm{m})\end{array}$ & Stratigraphy & $\begin{array}{c}\text { Aquifer } \\
\text { Depth } \\
\text { From - To }\end{array}$ & Thickness & $\begin{array}{l}\text { Diameter } \\
\text { inches }\end{array}$ & $\begin{array}{c}\text { Screen } \\
\text { Length } \\
\text { m }\end{array}$ & $\begin{array}{c}\text { Water } \\
\text { S.W.L. } \\
\text { m }\end{array}$ & $\begin{array}{l}\text { Dynamic } \\
\text { Level m }\end{array}$ & $\begin{array}{c}\text { Drawdo wn } \\
\text { m }\end{array}$ & $\begin{array}{l}\text { Yield } \\
\mathbf{m}^{3} / \mathbf{h}\end{array}$ & $\begin{array}{l}\text { Specific } \\
\text { Capacity }\end{array}$ \\
\hline Mokwa & 160 & 99.1 & $\begin{array}{l}\text { Nupe Sand } \\
\text { Stone }\end{array}$ & $74.7-99.1$ & 24.4 & 4 & 6.5 & 73.4 & 73.7 & 0.3 & 5.5 & 18.33 \\
\hline Mokwa & 160 & 96.0 & $\begin{array}{l}\text { Nupe Sand } \\
\text { Stone }\end{array}$ & $74.1-96.0$ & 21.9 & $5 / 8$ & 7.9 & 70.0 & - & - & 6.4 & - \\
\hline Mokwa & 110 & 76.7 & $\begin{array}{c}\text { Nupe Sand } \\
\text { Stone }\end{array}$ & $35.0-76.7$ & 41.7 & $5 / 8$ & 2.2 & 35.0 & 36.7 & 1.7 & 4.9 & 2.88 \\
\hline Mokwa & 130 & 85.6 & $\begin{array}{l}\text { Nupe Sand } \\
\text { Stone }\end{array}$ & $48.5-85.6$ & 37.1 & 6 & - & 48.5 & 52.2 & 3.7 & 18.2 & 4.92 \\
\hline Mokwa & 160 & 91.4 & $\begin{array}{l}\text { Nupe Sand } \\
\text { Stone }\end{array}$ & $71.9-91.4$ & 19.5 & $5 / 8$ & 13.7 & 71.9 & - & - & 14.6 & - \\
\hline Mokwa & 140 & 78.0 & $\begin{array}{c}\text { Nupe Sand } \\
\text { Stone }\end{array}$ & $57.3-78.0$ & 20.7 & $5 / 8$ & 10.3 & 57.8 & - & - & 13.6 & - \\
\hline Mokwa & 110 & 51.2 & $\begin{array}{l}\text { Nupe Sand } \\
\text { Stone }\end{array}$ & $32.3-51.2$ & 18.9 & 6 & 12.1 & 32.3 & - & - & 8.2 & - \\
\hline Mokwa & 130 & 73.0 & $\begin{array}{l}\text { Nupe Sand } \\
\text { Stone }\end{array}$ & - & - & 6 & 2.3 & 53.6 & 54.6 & 1.0 & 4.9 & 4.9 \\
\hline Mokwa & 10 & 50.3 & $\begin{array}{c}\text { Nupe Sand } \\
\text { Stone }\end{array}$ & 31.4 .50 .3 & 18.9 & 4 & 4.2 & 31.4 & - & - & 5.6 & - \\
\hline Shonga & 120 & 62.8 & $\begin{array}{l}\text { Nupe Sand } \\
\text { Stone }\end{array}$ & $36.5-62.8$ & 26.3 & 6 & 9.5 & 36.5 & - & - & 10.0 & - \\
\hline Kutigi & 75 & 38.8 & Alluvium & $0.9-30.5$ & 29.6 & 8 & - & 0.9 & 7.0 & 6.1 & 136.5 & 22.37 \\
\hline Kutigi & 140 & 44.8 & $\begin{array}{c}\text { Bida Sand } \\
\text { Stone }\end{array}$ & $14.6-16.1$ & 1.5 & - & - & 9.1 & 37.8 & 29.7 & 4.1 & - \\
\hline Kutigi & 140 & 158.5 & $\begin{array}{l}\text { Bida Sand } \\
\text { Stone }\end{array}$ & $14.6-16.1$ & 1.5 & 8 & - & 9.1 & 79.1 & 70.1 & 4.6 & 0.06 \\
\hline Kutigi & & & & & & 4 & 9.2 & 15.8 & - & - & - & - \\
\hline Bida & 150 & 62.5 & $\begin{array}{l}\text { Bida Sand } \\
\text { Stone }\end{array}$ & - & - & - & 7.9 & 12.8 & 24.4 & 11.6 & 9.1 & 0.78 \\
\hline Bida & 150 & 185.9 & $\begin{array}{c}\text { Bida Sand } \\
\text { Stone }\end{array}$ & $35.0-53.3$ & 18.3 & - & 12.5 & 18.9 & - & - & 6.4 & - \\
\hline Bida & 140 & 65.2 & $\begin{array}{c}\text { Bida Sand } \\
\text { Stone }\end{array}$ & $8.5-65.2$ & 56.7 & $5 / 8$ & 28.4 & 8.2 & - & - & 6.6 & - \\
\hline Bida & 150 & 62.5 & $\begin{array}{c}\text { Bida Sand } \\
\text { Stone }\end{array}$ & $22.9-62.5$ & 39.6 & $5 / 8$ & 9.4 & 22.9 & - & - & 3.2 & - \\
\hline Bida & 150 & 47.2 & $\begin{array}{c}\text { Bida Sand } \\
\text { Stone }\end{array}$ & $14.3-47.2$ & 32.9 & 6 & - & 14.3 & - & - & 4.6 & - \\
\hline Bida & 150 & 50.0 & $\begin{array}{c}\text { Bida Sand } \\
\text { Stone }\end{array}$ & $96.5-50.0$ & 33.5 & 6 & 9.4 & 16.5 & - & - & 4.5 & - \\
\hline Bida & 150 & 61.0 & $\begin{array}{l}\text { Bida Sand } \\
\text { Stone }\end{array}$ & - & - & 8 & 20.9 & 19.8 & - & - & 4.8 & - \\
\hline Bida & 150 & 67.0 & $\begin{array}{c}\text { Bida Sand } \\
\text { Stone }\end{array}$ & - & - & 8 & 3.9 & 18.3 & - & - & 4.8 & - \\
\hline Bida & 150 & 61.0 & $\begin{array}{c}\text { Bida Sand } \\
\text { Stone }\end{array}$ & - & - & 8 & 12.2 & 15.3 & - & - & 4.8 & - \\
\hline Badeggi & 75 & 82.3 & $\begin{array}{c}\text { Bida Sand } \\
\text { Stone }\end{array}$ & - & - & $5 / 8$ & 9.7 & 16.8 & - & - & - & - \\
\hline Badeggi & 75 & 76.2 & $\begin{array}{c}\text { Bida Sand } \\
\text { Stone }\end{array}$ & - & - & 6 & 3.4 & 18.3 & 22.0 & 3.7 & 3.2 & - \\
\hline Lafiagi & 85 & 36.6 & $\begin{array}{c}\text { Bida Sand } \\
\text { Stone }\end{array}$ & $16.8-29.0$ & 12.2 & $5 / 8$ & 3.0 & 16.8 & 25.6 & 8.8 & 37.7 & 4.28 \\
\hline Lafiagi & 85 & 35.2 & $\begin{array}{c}\text { Bida Sand } \\
\text { Stone }\end{array}$ & $15.2-20.5$ & 15.3 & 8 & 9.2 & 8.2 & 10.9 & 2.7 & 41.0 & 15.2 \\
\hline Lafiagi & 85 & 132.6 & Alluvium & $126.5-129.5$ & 3.0 & 8 & 3.0 & +1.2 & 62.8 & 64.0 & 2.8 & 0.04 \\
\hline Doko & 170 & 57.9 & Alluvium & - & - & 10 & 3.3 & $1+1$ & 41.6 & 30.5 & 7.3 & 0.24 \\
\hline Pategi & 100 & 131.1 & $\begin{array}{l}\text { Nupe Sand } \\
\text { Stone }\end{array}$ & $128.0-131.1$ & 3.1 & $5 / 8$ & 2.2 & 6.7 & 35.4 & 28.7 & 19.6 & 0.68 \\
\hline
\end{tabular}




\begin{tabular}{|c|c|c|c|c|c|c|c|c|c|c|c|c|}
\hline Pategi & 100 & 89.9 & $\begin{array}{c}\text { Stone } \\
\text { Nupe Sand } \\
\text { Stone }\end{array}$ & $73.1-76.2$ & 3.1 & 6 & 4.4 & - & - & - & 4.1 & - \\
\hline Lapai & 145 & 66.8 & & $82.6-89.3$ & 7.1 & 6 & 9.0 & 11.59 & 13.70 & 2.11 & - & - \\
\hline Kutigi & 140 & 115 & $\begin{array}{c}\text { Bida Sand } \\
\text { Stone }\end{array}$ & $54-66.6$ & 12.6 & 6 & 12 & 8.7 & 15 & 6.3 & 3.12 & 0.49 \\
\hline
\end{tabular}

\subsection{Occurrence of Groundwater}

The distribution and circulation of groundwater are controlled by geological factors such as the lithology, texture and structure of the rocks and by hydrological and meteorological factors such as stream flow and rainfall. Groundwater occurs both in confined and unconfined condition. In the study area, two types of aquifer are identifiable; one is semi-confined but locally confined in some places, while the other is unconfined. The first is most widespread and occupies about $80 \%$ of the land area, while the second is limited to small portions of the central and northern part of the basin[5,6].

\subsection{Aquifer Thickness and Lateral Extent}

The unit aquifer (Nupe Sandstone) spreads over a large area within the Middle Niger Basin. At Mokwa area the average thickness is about $28 \mathrm{~m}$. The aquifer at the southern part of River Niger spreads as a belt along the basement complex boundary. This belt runs from Jebba in the north-west to Lokoja in the south-east having a maximum width of $30 \mathrm{~km}$ [7]. From the available data (Table 1) it could be seen that the thickness of the aquifer increases in a south-east direction and amounts to the following:

La fiag i 3.0m (B.H. No.30) (126.5m to $129.5 \mathrm{~m})$

Pategi 9.0m (B.H. No.34) (128.3m to $137.2 \mathrm{~m})$

Kpada 33.5 m (B.H. No.39) (146.3m to $179.8 \mathrm{~m}$ )

The Nupe sandstone aquifer seems to completely thin out at the edges of Middle Niger Basin. This is confirmed by Share borehole (B.H. No.40) where the depth to the basement is about $33 \mathrm{~m}$.

\subsection{Piezometric Characteristics}

The Nupe Sandstone is unconfined at Mokwa area. The static water level varies between $31-72.5 \mathrm{~m}$. Averagely the static water level is about $49 \mathrm{~m}$. At Pategi area, the top of the aquifer is met at the depth of $128 \mathrm{~m}$ to $143 \mathrm{~m}$ (B.H. No. 32 \& 33). The static water level is between $0.3-15.2 \mathrm{~m}$. In Lafiagi, the Nupe sandstone confined aquifer acquired a flowing artesian character. Here the top of the aquifer is at the depth of $126.5 \mathrm{~m}$ (B.H.30). The static water level is $1.2 \mathrm{~m}$ above land surface with the corresponding head pressure of $127.7 \mathrm{~m}$.

\subsection{Water Yiel ding Properties of the Aquifers}

Du Preez and Barber[8] reported the occurrence of large quantities of groundwater from the Nupe sandstones in the area between Kontagora and Mokwa. Eastward towards Bida, the formation changes laterally into fine-grained sand and silt from which poor yields were obtained. Yields of the boreholes penetrating the Nupe sandstone in Mokwa areas range from 0.9 to $18.2 \mathrm{~m}^{3} / \mathrm{hr}$. The specific capacity values range from 1 to $18.33 \mathrm{~m}^{3} / \mathrm{h} / \mathrm{m}$. In Pategi, the average yield is about $13.7 \mathrm{~m}^{3} / \mathrm{h}$ with specific capacity ranging between $0.4-0.8 \mathrm{~m}^{3} / \mathrm{h} / \mathrm{m}$. Average drawdown is about $27 \mathrm{~m}$ (Table 1).

The Bida sandstone is characterized by very low yield which range from $3.2 \mathrm{~m}^{3} / \mathrm{hr}$ to $9.1 \mathrm{~m}^{3} / \mathrm{hr}$ with an average yield of $4.5 \mathrm{~m}^{3} / \mathrm{hr}$. The average drawdown is about $11 \mathrm{~m}$ while the average specific capacity is about $0.8 \mathrm{~m}^{3} / \mathrm{h} / \mathrm{m}$. The alluvium areas are highly productive. They are characterized by direct continuity with the water of the river. The yield as observed in Shonga (B.H.12) is $136 \mathrm{~m}^{3} / \mathrm{hr}$.

\section{Hydraulic Characteristics}

The hydraulic properties of an aquifer are assessed by the values of its parameters such as coefficient of transmissivity, permeability or hydraulic conductivity, specific yield and storage coefficient. Transmissivity represents the water transmitting capacity of a un it width of the entire saturated thickness of the aquifer. On the other hand, it can be defined as the rate at which water of prevailing kinematic viscosity is transmitted through a unit width of the aquifer under a unit hydraulic gradient $[9,10]$. Both semi-equilibrium Jacob analysis and the Recovery method were used in the analysis of data obtained from pumping test.

\subsection{Semi -Equilibrium J acob Analysis}

The Jacob's method is based on the Theis's formula with some restriction in its application[11]

The Theis's equation is expressed as

$$
S=\frac{Q \cdot W(u)}{4 \pi K D}
$$

This reduces to

$$
S=\frac{2.30 Q}{4 \pi K D} \log \frac{2.25 K D t}{r^{2} S}
$$

where $\mathrm{Q}=$ discharge in $\mathrm{m}^{3} /$ day; $\mathrm{W}(\mathrm{u})=$ well functions of $\mathrm{u}$ represent an exponential integral; $\mathrm{K}=$ hydraulic conductivity in $\mathrm{m} /$ day; $\mathrm{D}=$ is the aquifer thickness or saturated thickness of the aquifer in meters and, $r=$ well radius in metres.

Equation (2) is solved by plotting linear drawdown versus logarithm of time and reading off two parameters: $s$, the single log cycle drawdown increment, and $t_{0}$, the time when the straight line portion of the plot extrapolated backwards cuts the zero drawdown axis. Transmissivity KD can then be calculated by substituting the values for $\mathrm{Q}$ and $\mathrm{S}$. Illustration of this is given in Figure 3. 


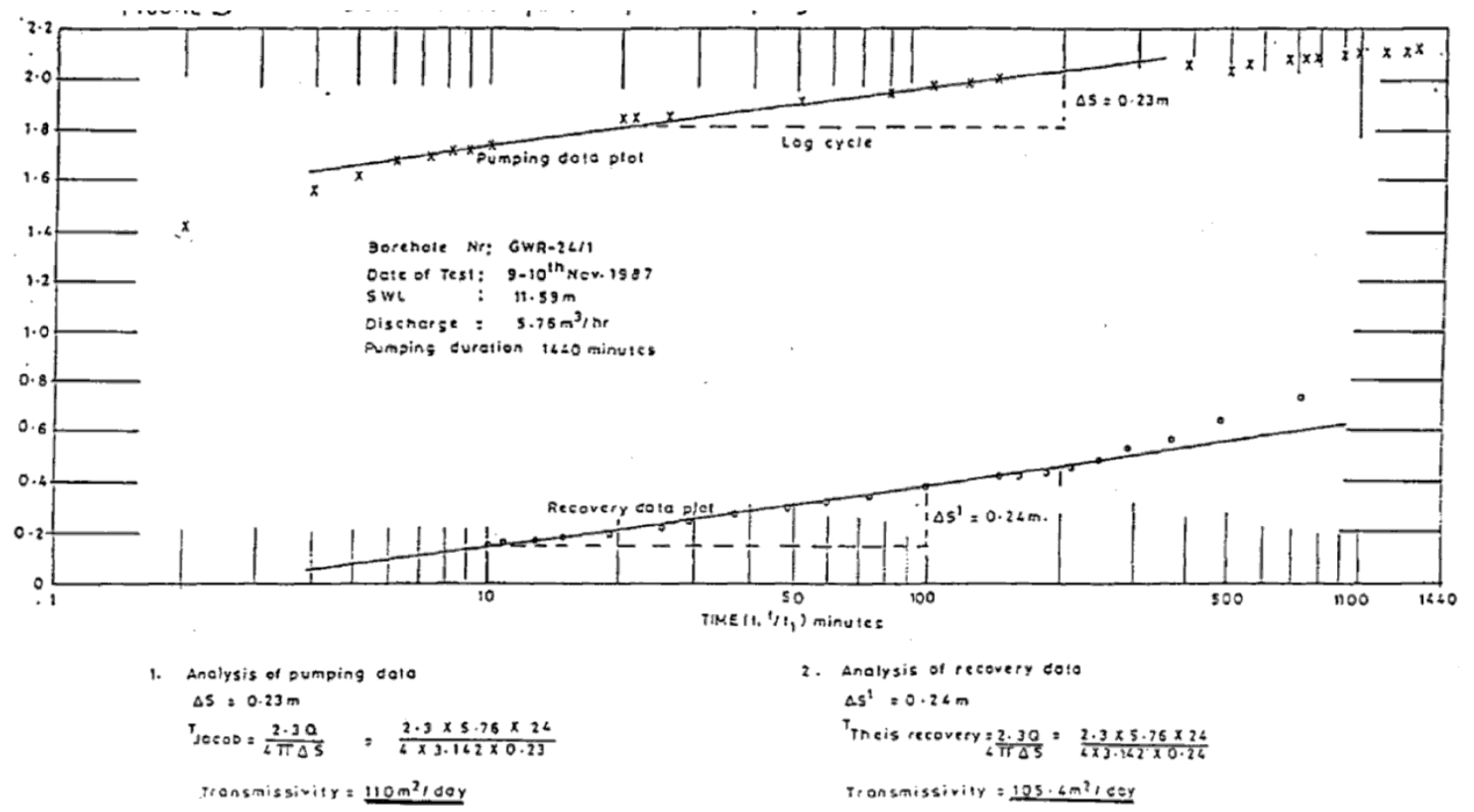

Figure 3. Central Mosque, Lapai-Pumping Test Data

Table 2. Main Hydrogeologic Parameters of Selected Boreholes in the Study Area

\begin{tabular}{|c|c|c|c|}
\hline S/N & Location & Transmissi vity & Yield $\left(\mathbf{m}^{\mathbf{3}} / \mathbf{d a y}\right)$ \\
\hline 1 & Lapai (Central Mosque) & 110 & \\
2 & Bida Fed.Govt.Col & 31.27 & 242 \\
3 & Mokwa & 123.55 & 230 \\
4 & Kutigi & 22.03 & 125 \\
5 & Doko & 4.87 & 312 \\
6 & Agaie & 7.86 & 69 \\
7 & Kaboji & 237 & 86 \\
8 & Boku & 393 & 154 \\
9 & Bida Guest.House & 1.40 & 69.6 \\
10 & Gbadako & 137 & 130 \\
11 & Mokwa Guest.House & 15.81 & 30 \\
12 & Etsu-Tasha & 1.365 & 86.4 \\
13 & Shabakolo & 12.44 & 30.2 \\
14 & Lokogoma & 10.62 & 91.8 \\
\hline
\end{tabular}

\subsection{Theis's Recovery Method}

Theis's recovery method can be used to calculate the hydraulic properties of an aquifer if the assumptions and conditions of Jacob's method are satisfied[11]. A p lot of $t / t$ " (on the log axis) against $S$ " yield a straight line whose slope is

$$
T=\frac{2.3 Q}{4 \pi \Delta S}
$$

Here $t$ is the time since pumping started, $t$ " is the time since pumping stopped, $\mathrm{s}$ " is the residual drawdown, $\mathrm{T}$ is transmissivity. An illustration of this method is presented in Figure 3. The transmissivity value of an aquifer can be calculated using any of the two methods. Table 2 is a compilation of the transmissivity values at different areas within the basin.

\section{Hydrogeochemistry of the Aquifers}

The chemical water characteristics described in this report are based on eleven analyses tabulated in Table 3. The above data were supplemented by field determination of electrical conductivity (E.C.) of some hand dug wells located in the study area. This method aims to indicate the quality of water by definition of total mineralization. The result of the exercise is given in Table 4. Figure 4 shows ranges of ma in chemical characteristics of analysed water. The predominant cations are calcium, sodium and manganese. The main anions are bicarbonate and chloride. Sulphate sometimes is also present. Iron content is generally negligible less than $0.3 \mathrm{mg} / 1$ except at Shonga, where $0.44 \mathrm{mg} / 1$ of iron was recorded. Manganese is predominantly absent. 
Table 3. ChemicalAnalysis of Groundwater from Bida Basin

\begin{tabular}{|c|c|c|c|c|c|c|c|c|c|c|c|}
\hline Location & Shonga & Share & Sunti & Mokwa & $\begin{array}{l}\text { (Well) } \\
\text { Mokwa }\end{array}$ & Pategi & Pategi & Kutigi & Lapai & \multicolumn{2}{|c|}{ MCRI Mokwa } \\
\hline Aquifer & Alluvium & & $\begin{array}{l}\text { Nupe } \\
\text { SD ST }\end{array}$ & & & $\begin{array}{l}\text { Nupe } \\
\text { SDST }\end{array}$ & $\begin{array}{l}\text { Nupe } \\
\text { SD ST }\end{array}$ & & & $\begin{array}{l}\text { Nupe } \\
\text { SDST }\end{array}$ & Badeggi \\
\hline Electrical Conductivity & 66.61 & & 34 & & - & 345 & 349 & 86 & & & \\
\hline Total Solids & 450.0 & 240 & 34 & 480 & 114.0 & 217 & $\begin{array}{l}349 \\
77\end{array}$ & 00 & 112 & 33 & 28 \\
\hline Total Hardness & 51 & 295.5 & $\overline{12}$ & & $\begin{array}{c}114.0 \\
-\end{array}$ & 140 & 115 & 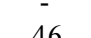 & & $\begin{array}{r}35 \\
18\end{array}$ & \\
\hline Total Alkalinity (As & 50 & 142.12 & 35 & & - & 141 & $\begin{array}{c}11.3 \\
12\end{array}$ & $\begin{array}{l}46 \\
35\end{array}$ & 64 & & \\
\hline $\left.\mathrm{CaCO}_{3}\right)$ & 6.8 & 377.5 & 6.5 & 5.6 & 6.1 & 6.9 & $\begin{array}{c}12 \\
7\end{array}$ & $\begin{array}{c}35 \\
625\end{array}$ & 186 & & \\
\hline $\mathrm{pH}$ & 1.08 & 8.4 & - & 24.0 & 50.0 & 39.0 & 58.0 & $\begin{array}{c}0.25 \\
50\end{array}$ & 7.8 & & 6.3 \\
\hline Silica $\left(\mathrm{Si}_{2}\right)$ & 45.0 & 20.0 & 3.0 & & & - & - & 50 & 0.02 & $\begin{array}{l}0.5 \\
105\end{array}$ & \\
\hline Free $\mathrm{CO}_{2}$ & 2.85 & - & 7 & Nil & 6.85 & 44.4 & 2.8 & 124 & & & \\
\hline Calcium $(\mathrm{Ca})$ & 12.16 & 21.02 & 3 & 0.4 & TR & 7.4 & 11 & $\begin{array}{l}12.4 \\
3.65\end{array}$ & 16.4 & & 2.6 \\
\hline Magnesium (Mg) & 12.10 & 25.94 & - & 1.7 & 2.6 & 9.4 & 1.9 & 3.03 & 5.34 & 2 & 0.6 \\
\hline Sodium $(\mathrm{Na})$ & - & דת. & & Nil & $\begin{array}{ll}2.0 \\
0\end{array}$ & 3.4 & 43 & - & & 0.729 & 1.5 \\
\hline Potassium (K) & 190 & - & 03 & 02 & $1 \mathrm{~K}$ & 20.2 & 4.3 & - & & 1.70 & 2.8 \\
\hline Total Iron $(\mathrm{Fe})$ & $\begin{array}{l}19.0 \\
0.44\end{array}$ & 0 & 0.3 & 0.2 & 0.04 & 1.2 & 0.05 & 0.05 & 0.12 & 1RACE & 0.05 \\
\hline Manganese (Mn) & 0.44 & 0.2 & Nil & 0.1 & & Nil & Nil & - & & & \\
\hline Ammonium $\left(\mathrm{NH}_{4}\right)$ & 1.04 & 0.1 & 2 & 0.004 & 0.004 & 0.1 & 0.04 & - & & & \\
\hline Aluminium $(\mathrm{Al})$ & - & - & - & 0.01 & Nil & 0.05 & 0.1 & - & & & \\
\hline Copper & - & - & - & Nil & & 0.04 & - & - & & & \\
\hline Boron & - & - & - & - & Nil & - & - & 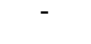 & & & Nil \\
\hline Zinc & $0 . \overline{98}$ & $\begin{array}{c}0.10 \\
-\end{array}$ & 6.83 & $\begin{array}{l}4.4 \\
7.0\end{array}$ & 4.0 & 12.7 & $\begin{array}{c}- \\
1.0\end{array}$ & 45 & & & \\
\hline Chloride & & & 8.00 & Nil & TR & $\mathrm{TR}$ & 1.5 & 5.0 & 0.12 & & 0.45 \\
\hline Sulphate & & & - & 13.7 & 9.0 & 172 & 15.7 & 21.4 & 1.98 & 2.88 & 0.37 \\
\hline $\begin{array}{l}\text { Bicarbonate } \\
\text {. }\end{array}$ & & Nil & Nil & 0.001 & - & 1.32 & $\mathrm{TR}$ & 1.9 & & & 03 \\
\hline $\begin{array}{c}\text { Nitrate Nitrogen }\left(\mathrm{NO}_{2}\right) \\
\text { Flouride }(\mathrm{F})\end{array}$ & 0.18 & & - & Nil & Nil & TR & TR & 0.3 & 008 & 5.48 & 0.3 \\
\hline Phosphorous $\left(\mathrm{P}_{3}\right)$ & 0.9 & & - & - & - & 0.28 & 0.16 & 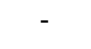 & 0.08 & & \\
\hline
\end{tabular}

Table 4. Electrical Conductivity of Selected Hand-Dug Wells

\begin{tabular}{|c|c|c|c|c|c|}
\hline No. & Locality & $\begin{array}{c}\text { Geological Unit } \\
\text { (m) }\end{array}$ & $\begin{array}{c}\text { Total Depth } \\
\text { (m) }\end{array}$ & Depth to Water & Electrical Condu ctivity (mmhos/cm) \\
\hline 1. & Lafiagi & Nupe Sandstone & 32.2 & 32 & 70 \\
\hline 2. & Bokani & Sandst one & 21.7 & 21.5 & 57 \\
\hline 3. & Lobizhi & Sandst one & 8.8 & 7.8 & 220 \\
\hline 4. & Kutigi & Bida Sandstone & 7.0 & 6.8 & 122 \\
\hline 5. & Enagi & Enagi Siltstone & 14.9 & 14.7 & 192 \\
\hline 6. & Kusegi & Bida Sandstone & 22.7 & 22.0 & 210 \\
\hline 7. & Batati & Bida Sandstone & 14.5 & 14.3 & 281 \\
\hline 8. & Bida & Bida Sandstone & 12.8 & 7.0 & 204 \\
\hline 9. & Badeggi & Bida Sandstone & 13.0 & 6.0 & 227 \\
\hline 10. & Badeggi & Bida Sandstone & 14.5 & 8.2 & 230 \\
\hline 11. & Lapai & Bida Sandstone & 12.1 & 12.0 & 267 \\
\hline 12. & Share & Nupe Sandstone & 8.4 & 5.8 & 140 \\
\hline 13. & Share & Nupe Sandstone & 13.8 & 13.8 & 145 \\
\hline 14. & Lafiagi & Nupe Sandstone & 19.7 & 19.7 & 285 \\
\hline 15. & Kpada & Nupe Sandstone & 19.5 & 19.5 & 110 \\
\hline 16. & Baro & Bida Sandstone & 17.0 & 16.8 & 180 \\
\hline 17. & Shonga & Alluvium & - & - & 66 \\
\hline 18. & Mokwa & Nupe Sandstone & - & - & 76 \\
\hline 19. & Doko & Bida Sandstone & - & - & 293 \\
\hline 20. & Bacita & Nupe Sandstone & - & - & 65 \\
\hline
\end{tabular}




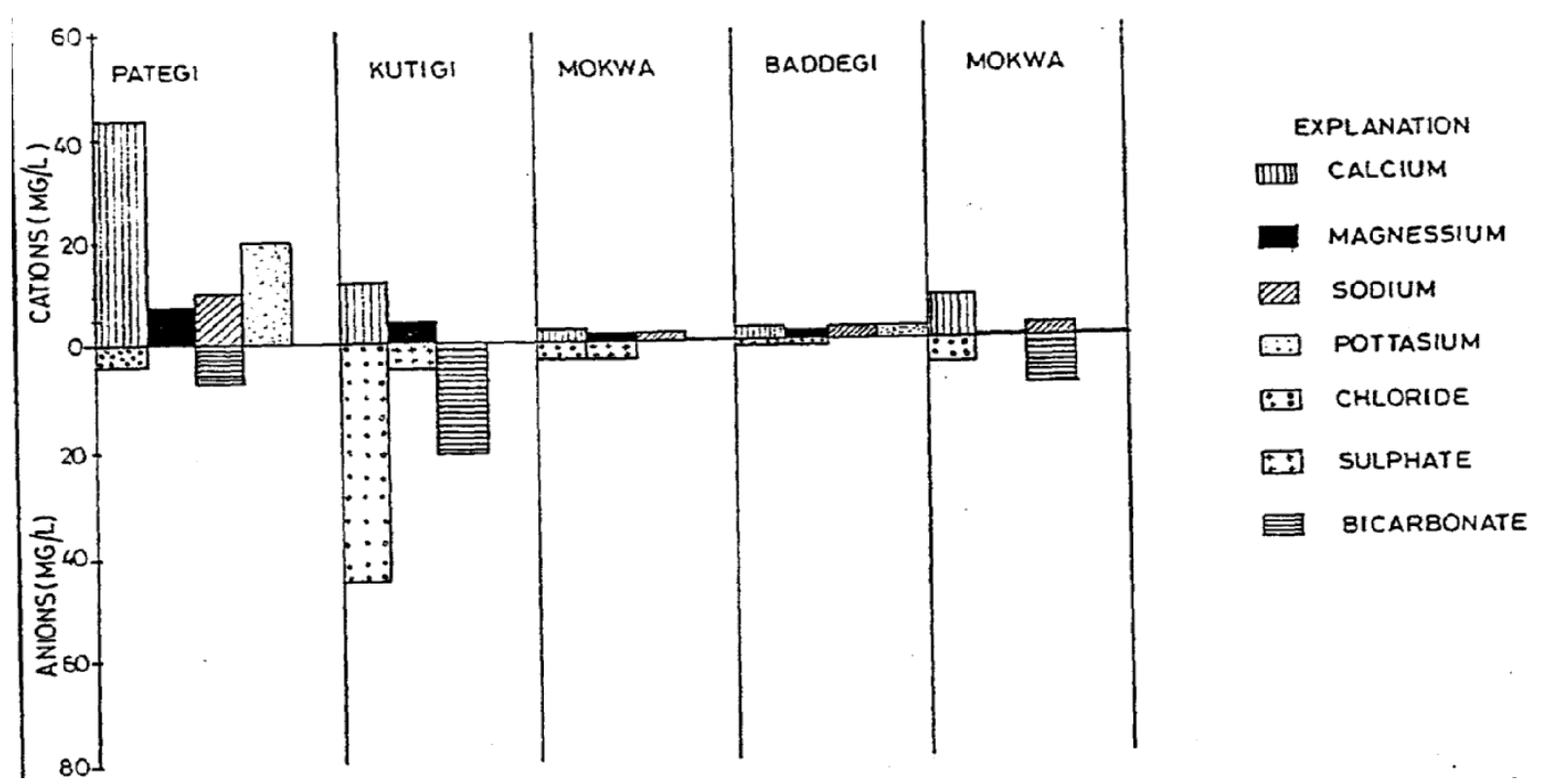

Figure 4. Bar Charts Illustrating Chemistries of Water from Selected Boreholes in the Study Area

Based on the classification system suggested by Gorell[12] which classify the quality of water based on TDS (Total Dissolved Solids) as shown below, it could be seen that the groundwater in this basin is fresh.

Freshwater 0-1,000mg/1 TDS;

Brackish water 1,000 -10,000mg/1 TDS;

Saline water $10,000-100,000 \mathrm{mg} / 1 \mathrm{TDS}$;

Brine $>100,000 \mathrm{mg} / 1$ TDS.

Even the highest values for the TDS obtained in this basin will fall far below the upper limit of the freshwater classification. Generally the water is free of chemical pollution and is therefore suitable for many purposes especially for irrigation.

The above conclusion agreed with the result of the study carried out by Kehinde and Loenhert[13] on the isotope analysis of water samples from the basin, and with similar studies by Bala and Onugba[14] as well as Olaniyan et al[15]. Results from the study reveal two water types: a poorly mineralised $\mathrm{Ca}\left(\mathrm{HCO}_{3}\right)_{2}$ to the north of the basin across the River Niger and a more mineralized $\mathrm{NaHCO}_{3}$ type limited to the south of the Niger. The analysis also reveals that more water samples fit the meteoric water line and that the water contained tritium which is an indication of active recharge.

\section{Summary of Major Findings}

The main findings from this study are summarized as follows:

i. The region is underlain by sedimentary rocks which vary in thickness from $40 \mathrm{~m}$ to $300 \mathrm{~m}$. The formation material consists mainly of very fine to coarse grain pebbly sandstone.

ii. Two major aquifer types have been identified in the study area i.e. confined and unconfined aquifer. The aquifer ranges between 3 and 34 meters thick and is composed of fine to medium grained, poorly sorted sandstones. Large quantities of groundwater occur in the sediments of the basin especially in the alluvium areas of Shonga, Baddegi and Lafiagi. The vast underground resources in the area can be used for agricultural purposes.

iii. The evaluation of hydrogeological parameters of boreholes obtained from pumping test analysis gave borehole yield ranging from $0.9 \mathrm{~m}^{3} / \mathrm{hr}$ to $136.5 \mathrm{~m}^{3} / \mathrm{hr}$. The high variability of borehole y ield in this basin is due to rapid changes in its hydrogeological characteristics.

iv. Average transmissivity values computed using Jacob and Theis' methods range between 1.365 and $393 \mathrm{~m}^{3} /$ day.

$\mathrm{v}$. The water in this basin is very soft and portable. It can be used for domestic, agricultural or industrial purposes. The electrical conductivity which is an indication of the general level of mineralization ranges from 34-349 micro $-\mathrm{ohm} / \mathrm{cm}$.

\section{REFERENCES}

[1] Falconer, J.O. (1911). The Geology and Geography of Northern Nigeria. Macmillan, London, pp 295.

[2] NWRI (2008). The Gusau 2006 Flood Studies. A research work by the Land and Water Division, National Water Resources Institute, Kaduna

[3] Dessavagie, F.E. (1972). Stratigraphy of the Niger Embankment near Bida, Nigeria In: African Geology, University of Ibadan Press.

[4] Adeleye, D.R. (1973). The Geology of the Middle Niger Basin. In: Geology of Nigeria. Edited by CA. Kogbe, Elizabethan Press, Lagos pp 283-287

[5] Shekwolo, P.D. (1990). Development and maintenance of groundwater resources - Bida Basin case study. A paper presented at International seminar on Hydrology, Maiduguri. 
[6] Olaniyan, I.O. and S.M. Oyeyemi (2008). Geophysical exploration for groundwater potential at Hay in Danmani area of Kaduna, Nigeria. Global Journal of Engineering and Technology 1(4): 413-418. Global Research Publication, Calcutta, India. eegjet2007@rediffmail.com

[7] Polservice (1979). A pre-drilling hydrogeological investigation Report, Area XVII. A study sponsored by Federal Ministry of Water Resources, Nigeria.

[8] Du Preez J.W. and Barber W. (1964). The distribution and chemical quality of groundwater in Northern Nigeria. G.S.N. Bulletin No.36.

[9] Todd, D.K (1980). Groundwater Hydrology. John Wiley \& Sons Inc.

[10] Diamond, J. and Shanley, T. (2003). Infiltration rate assessment of some major soils. Irish Geo graphy, Vol. 36(1): $32-46$

[11] Kruseman, G.P. and de Ridder, N.A. (1970). Analysis and evaluation of pumping test data. International Institute for
Land Reclamation and Improvement Bull.11, Wageningen, The Netherlands

[12] Gorell, H.A. (1958). Classification of foundation waters based on sodium chloride content. American Association of Petroleum Geologists Bulletin No 42 2513pp Washington D.C.

[13] Kehinde, M.O. and E.P. Loenhert (1989). Groundwater resources studies in the Bida Basin, central Nigeria. A paper presented at the 1 st International Water Resources Conference, Benin.

[14] Bala, A.E. and Onugba, A. (2001). Preliminary Chemical Assessment of Groundwater in the Basement Complex Area within the Bunsuru and Gagere sub-basin, Northern Nigeria. Journal of Mining and Geology. Vol. 37, No. 1. Published by the Nigerian Mining and Geosciences Society.

[15] Olaniyan, I.O., Agunwamba, J.C. and Ademiluyi, J.O. (2010). Assessment of aquifer characteristics in relation to rural water supply in part of northern Nigeria. Researcher 2(3):22-27, Marsland Press, New York, U.S.A. www.sciencepub.net. 